\title{
CLOSE ENCOUNTER WITH A BOREAL OWL
}

\author{
H. D. (SANDY) AYER, 115 Strandell Cresc. SW, Calgary, AB T3H 1K8, E-mail: \\ sayer@auc-nuc.ca
}

Since moving to Calgary in June 2003, I had been lamenting the comparative scarcity of birds in and around our yard. Back in Regina, from our house across from Wascana Creek, I'd accumulated a respectable yard list of 116 species in 15 years of birding. Now I was living across from an electrical substation and struggling to break the 20 species barrier. I was also missing the great vees of geese, ducks, Tundra Swans, and Sandhill Cranes (always with the hope of a Whooping Crane) that would wing their way south over our house every autumn. Avian grace intervened on the evening of 23 September, just after 9:00 p.m., as I was leaving the house to take Angelo, our pet sheltie, for a walk.

"Is it alive?" The voice belonged to Karen Cunningham, our next-door neighbor. She and her husband Mike and son Ryan were hunched over the splayed form of a bird on their driveway (Figure 1). The bird had struck their living room window with such force that they heard the sound while watching television at the other end of the house.
It was obviously a small owl. Quickly exchanging a disappointed Angelo for The Sibley Guide to Birds, I began observing the bird. When it first raised its head off the paving stones, I got a look at the streaking on its breast. In the poor light I couldn't tell what color brown it was, and so I initially concluded that it must be a Northern Saw-whet Owl.

The bird became more alert and swivelled its head almost 180 degrees, so that the garage light illuminated it enough to reveal a pale bill, a chocolate-colored upper body sprinkled (including the head) with small evenly-distributed white spots, and a facial disk with a broken black border that gave the face itself an angry look. The Northern Saw-whet is the most common small owl in these parts, ${ }^{4}$ but this owl lacked the Northern Saw-whet's white dorsal "braces," and as it extended itself to its full length (Figure 2), I could see that it was in fact larger than a Saw-whet, about the size of an American Robin, though bulkier. So there it was: my life Boreal Owl handed to me, as it were, on a silver platter. A couple

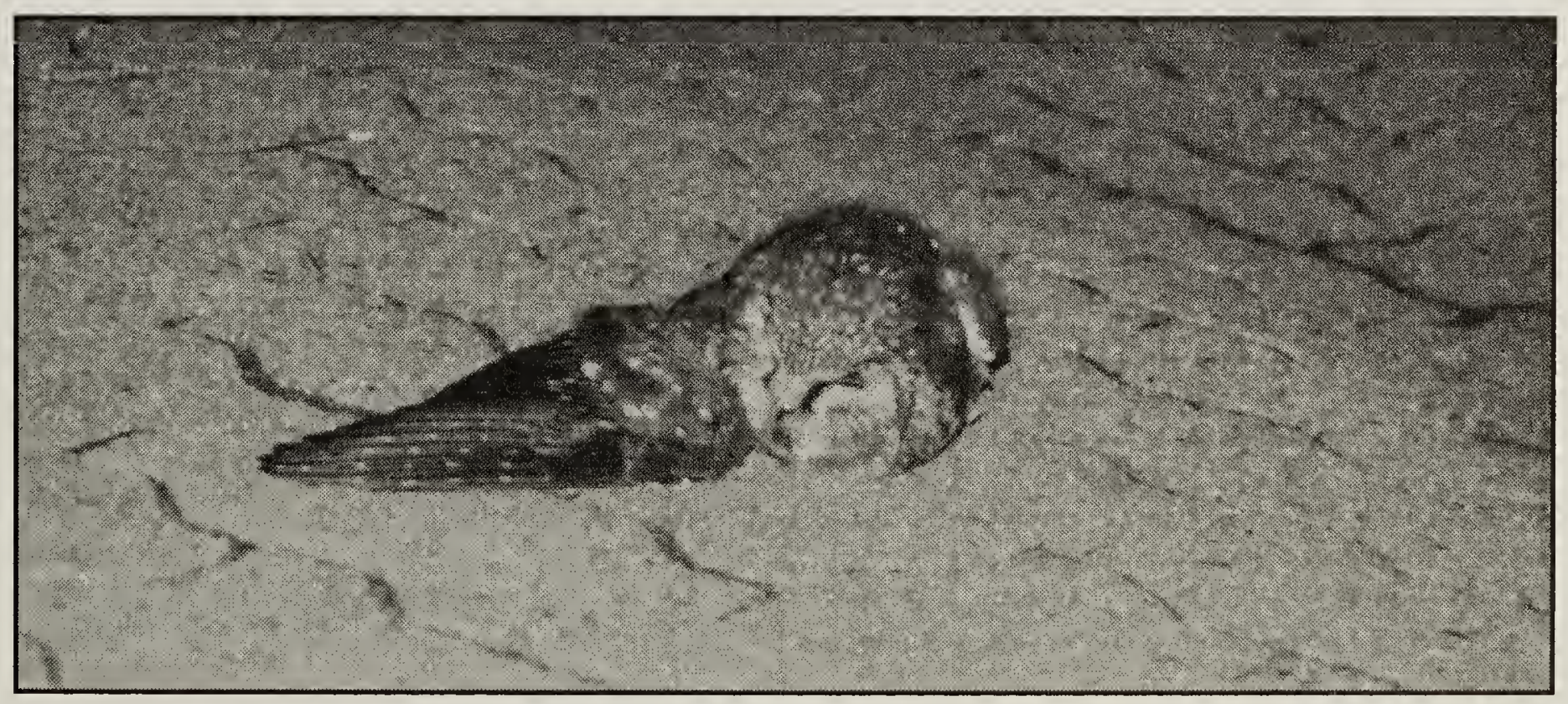

Figure 1. Splayed Boreal Owl on driveway 


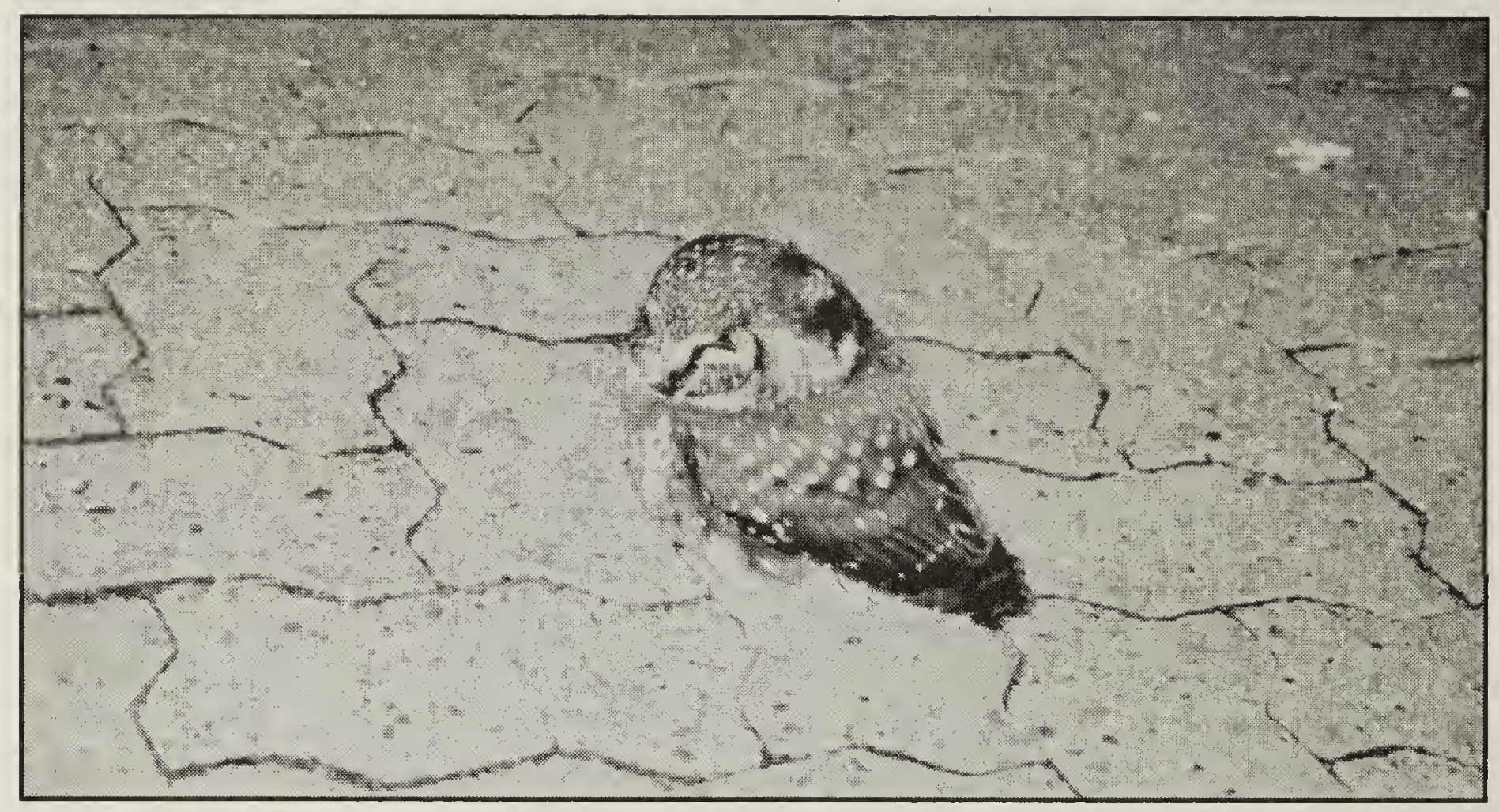

Figure 2. Boreal Owl recovering from collision impact

of minutes later, now fully recovered, the owl flew into the ash tree in our front yard to become my most memorable yard bird ever.

According to Birds of Alberta, the province "is one of the best places in the world to encounter this pint-sized owl, even though few birds are seen each year." Indeed, this was, according to Phil Cram, chair of the Calgary Field Naturalists' Society Bird Study Group, the first time anyone had seen a Boreal Owl in the city since 2000 . It was the first of three sightings for 2003, the last of which occurred on 14 December during the Christmas Bird Count (Phil Cram, pers. comm.).

But what had caused this owl of the boreal forest to crash into my neighbors' living room window? Had it panicked while fleeing a bird of prey? This seems plausible, although the only potential pursuer likely to be active at that time of night was the Great Horned Owl, which will kill any owl that intrudes into its territory. ${ }^{2}$ This species nests in Edworthy Park, a mere two km away, but to my mind the panic hypothesis still depended too much on coincidence to be convincing.
Was the owl perhaps itself pursuing prey at the time? House Sparrows roost in the ash tree in our front yard, but Boreal Owls in the Rockies rarely feed on birds, ${ }^{3}$ and then only when they have difficulty locating the voles, mice, and shrews that comprise their usual diet. ${ }^{2}$ The grassy field between our house and the substation probably holds lots of small mammals (I've heard them in the grass), so the owl wouldn't have had to resort to birds. However, it probably hadn't begun to hunt prey of any kind, for Boreal Owls usually don't begin searching for prey until at least two hours after sunset, ${ }^{2}$ and on this particular night sunset came at $7: 33$ p.m. ${ }^{5}$

Karen Cunningham thought that the flying owl had seen the reflection of nearby trees in the window, which was illuminated only by distant street lights, and simply failed to change course. I put the question via e-mail to owl expert Bill Lane, who agreed with Karen's assessment. This explanation also accords well with the Boreal Owl's flight patterns, for it "moves with ease through dense forest. Often it flies low under the thickest branches, sliding silently between the saplings and underbrush."2 
If this hypothesis is correct, then the owl could have been migrating (or, more properly, "irrupting"). Indeed, most accidents involving birds and stationary objects occur during migration. ${ }^{6}$ However, Boreal Owls' sporadic irruptions southward usually occur only once every four years or so in response to massive dieoffs in their mammalian prey. No irruption seems to have occurred in the winter of 2003, at least if the lack of reports on birding discussion lists is anything to go by. Hence, post-breeding dispersal, if the owl we saw was a juvenile, or simply the nomadic tendencies of both females and juveniles of the species, may best account for this particular bird's movements (Bill Lane, pers. comm.). Male Boreal Owls, by contrast, tend not to leave their territories unless prey is very scarce. ${ }^{2}$

I'd appreciate hearing from anyone who can shed any further light on the probable cause of this accident.

In the meantime, I continue to keep a close eye on my neighbors' house, for who knows when my life Northern Hawk and Northern Pygmy owls might just come crashing into their living room window?

\section{Acknowledgements}

I would like to thank Phil Cram for the information he provided on Boreal Owl sightings in Calgary; Bill Lane for his expert observations on the behavior of owls; Trevor Herriot, Tim Heath, Eric Greenway, and Diane Ayer for reviewing the manuscript; Saundra Lipton for database mercies; and Karen Cunningham for taking the photographs and for vocalizing her discovery at just the right time.

1. FISHER, C. and J. ACORN. 1998. Birds of Alberta. Lone Pine Publishing, Edmonton. p. 192.

2. HUME, R. and T. BOYER. 1991. Owls of the World. Dragon's World, Limpsfield, Surrey.

3. JOHNSGARD, P. A. 1992. Birds of the Rocky Mountains: With Particular Reference to National Parks in the Northern Rocky Mountain Region. University of Nebraska Press, Lincoln. p. 213

4. PINEL, H. W., et al. 2003. Checklist of the Birds of the Calgary Region. 6th ed. rev. Calgary Field Naturalists' Society.

5. SUNRISE AND SUNSET IN CALGARY, ALBERTA, CANADA. Cited 22 January 2004. Online http://www.timeanddate.com/ worldclock.astronomy.html? $\mathrm{n}=55$

6. TERRES, J. K. 1980. The Audubon Society Encyclopedia of North American Birds. Alfred A. Knopf, New York, N.Y., p. 3.

"The Birch Hills form the dividing ridge between the water which flows into the main

Saskatchewan and the Assiniboine, or Red Deer and Swan Rivers. The remarkable profusion of flowers gives extraordinary beauty to large open areas; they generally occur in parterres of several acres in extent occupied by one species, here the yarrow, there the

fireweed, then a field of a species of helianthus, followed by Liatris scariosa. When viewed from an eminence, the country appeared to be clothed with pink, white, yellow, and blue, in singular contrast to the uniform tint which prevails on the great prairies of the Little Souris." and of the Assiniboine and Saskatchewan Exploring Expedition of 1858, p. 407 